\title{
Mempertimbangkan Gagasan Hermeneutika Farid Esack untuk Membangun Kerukunan Hidup Umat Beragama
}

\author{
Oleh : Muhtarom
}

Fakultas Ushuluddin dan Humaniora Universitas Negeri Islam Walisongo Email: taromfu@gmail.com

\begin{abstract}
Abstrak
Tidak satu pun agama yang menganjurkan pemeluknya untuk melakukan kekerasan. Namun, tidak jarang terjadi tindak kekerasan yang dilakukan oleh masyarakat agamis, bahkan mereka yang mempunyai basis agama yang kuat dan mereka melakukannya dengan atas nama agama. Sebenarnya, gagasan untuk melakukan dialog dan kerja sama di antara umat beragama sudah sering dilakukan. Namun, semangat dan intensitas dialog tersebut masih banyak yang dilakukan atas dasar kepentingan sosiologis, politis atau sejenisnya. Ia belum dibarengi dengan perubahan dogma dan tata pikir keagamaan yang lebih mendasar, sehingga dialog, kerja sama dan kerukunan yang dihasilkan hanya merupakan kerukunan semu, bukan kerukunan yang tulus. Dalam konteks ini, hermeneutika kerukunan Farid Esack yang mengedepankan pluralisme dan inklusivisme agama layak dipertimbangkan untuk dikembangkan di Indonesia mengingat salah satu penyebab terjadinya ketegangan dan kekerasan yang bernuansa agama adalah ditonjolkannya pandangan dan sikap eksklusivisme agama.
\end{abstract}

\section{Abstract}

There is no religion encourages its adherents to commit violance. However, it is not rare acts of violence committed by religious peoples, even by those with a strong religious base and they do it in the name of their religion. In fact, the idea to undertake dialogue and cooperation among believers have often done. However, the passion and intensity of dialogue is still a lot that is done on the basis of sociological and political interests or the like. It has not been coupled with changes in dogma and the more fundamental religious thought, so the dialogue, cooperation and harmony that is generated is only an artificial unity, not a genuine unity. In this context, the "barmony" bermeneutics of Farid Esack uphold pluralism and religious inclusivism is worth considered for developed in Indonesia given one of the causes of tension and violence that the nuances of religion is accentuating the views and attitudes of religious exclusivism.

Key Word: Farid Esack; hermeneutika; pluralism; inklusifisme; kekerasan 


\section{Pendahuluan}

Kerukunan umat beragama merupakan modal dasar bagi terciptanya stabilitas nasional. Kerukunan umat beragama sendiri adalah keadaan hubungan sesama umat beragama yang dilandasi toleransi, saling pengertian, saling menghormati, menghargai kesetaraan dalam pengamalan ajaran agamanya dan kerjasama dalam kehidupan bermasyarakat, berbangsa dan bernegara. Upaya untuk menciptakan dan memelihara kerukunan umat beragama di tanah air tidak hanya menjadi tanggungjawab pemerintah tetapi juga tanggungjawab umat beragama itu sendiri. Sebenarnya pemerintah sendiri telah melakukan berbagai langkah dan upaya untuk memelihara kerukunan umat beragama tersebut, baik di bidang pelayanan, pengaturan, dan pemberdayaan umat beragama. Namun seperti yang terjadi selama ini, masih mudah terjadi benturan-benturan di masyarakat yang melibatkan umat beragama.

Kenyataan-kenyataan tersebut akhirnya mendorong para pemikir untuk menemukan konsep alternatif dan menyajikan agama yang sejuk serta damai. Muncullah gagasan-gagasan untuk melakukan dialog dan kerja sama di antara umat beragama. Namun, semangat dan intensitas dialog dan saling menyapa tersebut agaknya masih banyak yang dilakukan atas dasar kepentingan sosiologis, politis atau sejenisnya dan belum dibarengi dengan perubahan dogma dan tata pikir keagamaan yang lebih mendasar, sehingga dialog, kerja sama dan kerukunan yang dihasilkan hanya merupakan kerukunan semu, bukan kerukunan yang tulus, sehingga sedikit masalah telah mampu merusak kesepakatan dan dapat memicu terjadinya ketegangan.

Dalam konteks ini, barangkali kita bisa mempertimbangkan gagasan hermenutika al-Qur'an Farid Esack, seorang tokoh pemikir Islam asal Afrika Selatan. Ia mendobrak klaim kebenaran eksklusif agama untuk kemudian menggantinya dengan gagasan-gagasan pluralis dan membebaskan. Berdasarkan teori hermeneutikanya, Esack menjelaskan dan memberikan landasan teologis bagi terciptanya kerukunan umat beragama. Gagasan hermeneutika Esack ini kiranya patut untuk diperhatikan dan dijadikan bahan kajian untuk mengembangkan konsep kerukunan umat beragama di Indonesia yang masih rawan terjadinya konflik dan benturan. 


\section{Penyebab terjadinya Kekerasan/Konflik}

Tak ada yang memungkiri bahwa secara normatif, tidak ada satu pun agama yang menganjurkan pemeluknya untuk melakukan tindak kekerasan (violence). Akan tetapi, secara faktual, tidak jarang dijumpai tindak kekerasan yang dilakukan masyarakat agamis. Bahkan, ada kecenderungan bahwa kekerasan ini justru dilakukan oleh mereka yang mempunyai basis agama yang kuat dan mereka melakukannya dengan atas nama agama. Dua kasus kekerasan berbasis agama yang terjadi di Cikeusik Pendeglang Banten ${ }^{1}$ dan Temanggung $^{2}$ membuktikan sinyalemen ini. Mengapa terjadi kontradiksi antara ajaran normatif dengan praktek di lapangan? Inilah pertanyaan sederhana tetapi sulit dicari jawabannya.

Ada banyak motif yang menjadi penyebab terjadinya kekerasan/konflik. Ada kekerasan yang bermotifkan ekonomi, sosial, politik, dan SARA (Suku Agama dan Ras). Kekerasan yang bernuansa agama misalnya, bisa terjadi karena faktor eksternal maupun internal. Faktor-faktor eksternal, antara lain: masalah ekonomi, sosial, politik atau perilaku-perilaku menyimpang yang menyeret dan mengatasnamakan agama. Dalam realitasnya, tidak jarang kita melihat pada kasus-kasus kekerasan, kepentingan-kepentingan politik yang dibalut dengan dalil-dalil agama atau bahkan mengatasnamakan agama mampu menyeret emosi keagamaan masyarakat. ${ }^{3}$

Sementara faktor-faktor internal yang muncul dari diri agama sendiri, paling tidak ada tiga hal yang dapat menjadi akar atau setidaknya dapat mendorong terjadinya tindak kekerasan dalam agama. Pertama, adanya truth claim (klaim kebenaran). Secara normatif, truth claim dalam agama sebenarnya bukan sesuatu yang salah, bahkan ia adalah kenyataan yang tidak bisa

\footnotetext{
${ }^{1}$ Penyerangan Cikeusik adalah penyerangan yang dilancarkan oleh seribuan warga Desa Cikeusik terhadap jemaah Ahmadiyyah di Desa Umbulan, Cikeusik, Pandeglang, Banten pada hari Minggu, $\underline{6}$ Pebruari 2011, sekitar pukul 10.00 WIB. Akibat penyerangan ini, tiga orang tewas, sementara dua mobil, satu motor, dan satu rumah, hancur diamuk massa. Lihat https://id.wikipedia.org/wiki/Penyerangan_Cikeusik. Data diperoleh dari sumber Mediaindonesia.com, diakses pada 11 Pebruari 2011 dan Kompas.com, diakses pada 6 Pebruari 2011

2 Kekerasan di Temanggung adalah amuk massa menyusul kerusuhan dalam persidangan kasus penistaan agama dengan terdakwa Antonius Richmond Bawengan di Pengadilan Negeri Temanggung, Selasa $(8 / 2 / 2011)$. Dalam peristiwa ini, setidaknya tiga gereja rusak menjadi sasaran amuk massa. http://regional.kompas.com/ read/2011/02/08

3 Menurut Arifin Assegaf: kekerasan agama disebabkan oleh lima factor: (1) sikap ekslusifitas penganut suatu agama, (2) sikap tertutup dan saling curiga, (3) sikap yang berlebihan atas simbolsimbol agama, (4) perubahan perspektif atas agama yang awalnya merupakan tujuan menjadi alat, realitas menjadi sekedar kebijakan dan seterusnya, (5) kondisi politik, sosial dan ekonomi. Lihat Arifin Assegaf, "Memahami Sumber Konflik Antar Iman" dalam TH. Sumartana et. al, Pluralisme, Konflik dan Pendidikan Agama di Indonesia (Yogyakarta: Dian/ Interfidei, 2001), h. 34-37.
} 
dihindarkan. Agama tanpa truth claim ibarat pohon tanpa buah. Tanpa adanya truth claim yang oleh Whitehead disebut dogma dan oleh Rahman disebut transcendent aspect, agama hanya akan menjadi bentuk kehidupan (form of life) yang tidak memiliki kekuatan simbolik yang menarik pengikutnya. ${ }^{4}$ Akan tetapi, apabila truth claim diterapkan kepada pihak lain dan dipahami secara mentah serta emosional, ia justru akan menimbulkan banyak masalah. Truth claim dari suatu kelompok akan berbenturan dengan truth claim dari kelompok lain.

Dalam tradisi pemikiran Islam, realitas tersebut dapat dilihat pada benturan-benturan antara Syiah-Sunni-Khawarij, Mu'tazilah-Sunni, kelompok fiqih-sufi, antara penganut syariat-hakekat yang terjadi pada awalawal abad sejarah Islam. Sementara di tanah air, benturan-benturan kekerasan bernuansa agama sering mewarnai perjalanan sejarah negeri ini. Berbagai kekerasan di Ambon, kekerasan terhadap pengikut Ahmadiyah dan lainnya merupakan deretan akibat truth claim yang tidak diterapkan secara tepat.

Kedua, adanya sikap yang berlebihan atau tepatnya pensakralan atas ide, gagasan dan pemikiran-pemikiran keagamaan yang oleh Arkoun diistilahkan dengan taqdîs al-fiker al-dini. ${ }^{5}$ Pada kebanyakan masyarakat Islam, teks-teks keagamaan yang diikuti dan dijadikan rujukan bukan sekedar alQur`an dan hadis sahih tetapi mencakup juga pemikiran-pemikiran ulama produk abad pertengahan seperti yang tertulis dalam kitab-kitab kuning. Kitab-kitab kuning ini bahkan telah dianggap sebagai sesuatu yang sempurna, komprehensip dan menjawab segala persoalan umat, sehingga tidak ada lagi kritik, baik ontologis, epistemologis maupun aksiologis. Yang diperlukan hanya penjabaran (syarb) atas kitab-kitab tersebut, bukan ijtihad dalam arti yang sesungguhnya. Posisi umat Islam terhadap kitab kuning ini, menurut mereka, hanya sebatas mereproduksi wacana dan bukan memproduksi wacana baru. ${ }^{6}$ Sikap yang berlebihan dalam membela dan memegang pemikiran keagamaan ini kemudian melahirkan kelompokkelompok keagamaan yang berbeda-beda (polarisasi) di masyarakat. Pada

4 Sebagaimana dikutip oleh Ahmad Khudlori Soleh dalam "Kekerasan Religius" dari Fazlur Rahman "Approach to Islam in Religious Studies Review Essays" dalam Richard C. Martin (ed), Approach to Islam in Religious Studies (Tuscon: The University of Arizona, 1985), h. 194; dan Alfred North Whitehead, Religion in the Making (New York: New American Library, 1974), h. 57. Diunduh dari wnw.scribd.com

${ }^{5}$ M. Arkoun, Al-Islam al-Akhlâq wa al-Siyâsah (Beirut: Markaz al-Inma`al-Qaumi, 1990), h. 172-3

${ }^{6}$ Ahmad Khudlori Soleh dalam "Kekerasan Religius" dalam wmw.scribd.com 
gilirannya adanya polarisasi keagamaan masyarakat ini dapat menimbulkan benturan-benturan sosial.

Ketiga, adanya doktrin untuk menyebarkan agama (dakwah). Setiap pemeluk agama pasti menyakini bahwa agama yang dianutnya adalah benar. Bahkan, keyakinan benar dalam agama tersebut tidak untuk dirinya sendiri melainkan harus juga disebarkan, karena salah satu misi penting agama adalah memberikan petunjuk dan keselamatan bagi manusia. Al-Qur an sendiri sering mengklaim sebagai pemberi petunjuk yang benar dan memerintahkan umatnya untuk menyebarkan ajaran- ajarannya kepada orang lain, terlepas mereka mau menerima atau tidak. Ini sebenarnya sesuatu yang lumrah dalam sebuah agama atau bahkan dogma dan idiologi. Namun, perilaku dakwah yang dilaksanakan secara kasar dan tidak beretika justru akan menimbulkan banyak masalah. Kenyataannya, ketegangan dan kekerasan antar umat beragama sering terjadi karena masalah ini.

\section{Mengenal Sosok Farid Esack}

Maulana Farid Esack lahir tahun 1959 di Cape Town, daerah pinggiran kota Wynberg, Afrika Selatan. Ia berasal dari keluarga miskin yang hidup bersama ibu dan lima saudara, sehingga ibunya harus bekerja sebagai buruh cuci untuk menghidupi anak-anaknya. ${ }^{8}$ Pendidikan dasar dan menengahnya ditempuh di Bonteheuvel.Pada usia 9 tahun, Esack bergabung dengan Jama'ah Tabligh dan pada usia 10 tahun dia sudah menjadi guru di sebuah madrasah lokal. ${ }^{9}$

Tahun 1974, Esack ditahan dinas kepolisian Afrika Selatan karena dianggap merongrong pemerintahan rezim Apartheid, saat itu usianya 15 tahun. Namun, tidak lama kemudian ia dibebaskan dan kemudian pergi ke Pakistan untuk melanjutkan studinya. Di Pakistan, Esack melanjutkan studi di Seminari (Islamic College) dengan dana beasiswa. Dia menghabiskan waktu studinya selama sembilan tahun (1974-1982) sampai mendapat gelar kesarjanaan di bidang teologi Islam dan sosiologi pada Jamîah al-Ulûm alIslâmiyyah, Karachi ${ }^{10}$. Setelah itu, ia pulang ke Afrika Selatan karena tidak tahan melihat negaranya sedang berjuang melawan Apartheid. Selama di

\footnotetext{
7 Ibid.

${ }^{8}$ Farid Esack, Membebaskan Yang Tertindas, Al-Qur'an Liberalisme Pluralisme, terj. Watung Budiman (Bandung: Mizan, 2000), h. 24

${ }^{9}$ bttp:// www. farid esack.com

${ }^{10} \mathrm{Ibid}$. sumber lain menyebutkan, ia sempat kuliah di Jami'ah al-Ulum al-Islamiyah dan kemudian menyelesaikan sarjananya di Jami'ah 'Alimiyah al-Islamiyah Pakistan. Lihat Dadi Darmadi "Kata Pengantar” untuk terjemah buku Farid Esack, On Being A Muslim, Menjadi Muslim di Dunia Modern, terj. Dadi Darmadi dan Jajang Jahroni, (Jakarta: Erlangga, 2004), h. xiii
} 
tanah airnya ini, Esack bersama beberapa temannya membentuk organisasi politik keagamaan, The Call of Islam dan ia menjadi koordinator nasionalnya. Melalui organisasi ini, Esack berkeinginan dan berjuang keras untuk menemukan formulasi Islam khas Afrika Selatan, berdasarkan pengalaman penindasan dan upaya pembebasan yang disebutnya sebagai $a$ search for an outside model of Islam. ${ }^{11}$

Setelah 8 tahun berjuang di tanah airnya, pada tahun 1990, Esack kembali ke Pakistan untuk melanjutkan studinya di Jami'ah Abi Bakr, Karachi. Di sini dia menekuni Studi Qur'an (Qur'anic Studies). Sekembalinya dari anak benua India, di tengah-tengah aktivitas sosial keagamaannya yang penuh resiko karena menentang pemerintahan Apartheid di Afsel, pada tahun 1994 Esack melanjutkan studinya untuk menempuh program Doktor di Pusat Studi Islam dan Hubungan Kristen-Muslim (Centre for the Study of Islam and Christian-Muslim Relations [CSIC]) University of Birmingham (UK), Inggris. Puncaknya, tahun 1996, Esack berhasil meraih gelar Doktor di bidang Qur'anic Studies dengan desertasi berjudul Qur'an, Liberation and Pluralism: an Islamic Perspective of Inter-religious Solidarity Against. ${ }^{12}$

Pada tahun 1994-1995, Esack menjadi peneliti pada Biblical Hermeneutics di Philosophische Theologische Hochschule, Sankt Georgen, Frankfurt, Jerman. Sepulang dari Eropa, ia tercatat sebagai assosiate professor dalam studi Islam di University of Western Cape, Afrika Selatan. ${ }^{13}$ Ia juga pernah memegang jabatan penting di berbagai lembaga dan organisasi, seperti The Organisation of People Aginst Sexism dan The Capé Against Racism and the World Conference on Religion and Peace. Dia juga rutin menjadi kolumnis politik di Cape Time (mingguan), Beeld and Burger (dua mingguan), koran harian South African dan kolumnis masalah sosial-keagamaan untuk al-Qalam, sebuah tabloid bulanan muslim Afrika Selatan. Ia juga menulis di Islamica, Jurnal tiga bulanan umat Islam di Inggris serta jurnal Assalamu'alaikum, sebuah jurnal muslim Amerika yang terbit tiga bulan sekali. ${ }^{14}$

Dalam bidang akademik, Esack pernah menjabat sebagai dosen senior pada Department of Religius Studies di University of Western Cape sekaligus Dewan Riset Project on Religion Culture and Identity. Di samping itu, ia juga pernah menjabat sebagai Komisaris untuk Keadilan Jender, dan guru besar tamu dalam Studi Keagamaan (Religious Study) di Universitas

\footnotetext{
${ }^{11}$ Farid Esack, op. cit.i, h. 29

12 Ibid.

${ }^{13}$ Farid Esack, On Being A Muslim, h. xiv

14 bttp:/ / www.farid esack. com
} 
Hamburg, Jerman. Esack juga pernah memimpin banyak LSM dan perkumpulan, antara lain Community Development Resource Association, The Aids Treatment Action Campaign, Jubilee 2000 dan Advisory Board of SAFM. ${ }^{15}$

Saat ini, waktunya banyak dihabiskan untuk mengajar berbagai mata kuliah yang bertalian dengan masalah keislaman dan muslim di Afrika Selatan, teologi Islam, politik, environtalisme dan keadilan jender di sejumlah universitas di berbagai penjuru dunia, antara lain, Amsterdam, Cambridge, Oxford, Harvard, Temple, Cairo, Moscow, Karachi, Birmingham, Makerere (Kampala) Cape Town dan Jakarta. ${ }^{16}$

\section{Latarbelakang Hermeneutika Farid Esack}

Menurut Farid Esack, hermeneutika mengasumsikan bahwa setiap orang mendatangi teks dengan membawa persoalan dan harapannya sendiri, dan "adalah tidak masuk akal untuk menuntut mufassir menyisihkan subyektiftas dirinya dan menafsirkan suatu teks tanpa pemahaman dan pertanyaan awal yang dimunculkannya (karena tanpanya) teks itu bungkam". ${ }^{17}$ Hermeneutika berisikan komponen iedologis, sikap, dan metodologi yang dirancang untuk membantu usaha interpretasi dan memudahkan pemahaman yang maksimal.

Dalam hal ini, ada beberapa realitas yang mendasari Esack dalam menyusun hermeneutika al-Qur'an, yaitu:

a. Seseorang tak mungkin lepas dari pengalaman pribadi dan sosial yang membentuk keutuhan eksistensinya ketika membaca teks.

b. Usaha seseorang untuk memaknai apa pun yang dibaca dan dialaminya senantiasa berlangsung dalam konteks tertentu. Demikian pun kepada alQur'an, mustahil mendapatkan interpretasi atasnya yang berlaku untuk seluruh dunia. Penafsiran selalu bersifat tentatif dan bias.

c. Menurut al-Qur'an, manusia akan tiba pada keyakinan yang benar (ortodoksi) melalui tindakan yang benar (ortopraksis). Yang terakhir menjadi kriteria untuk menetapkan yang pertama. Dalam suatu masyarakat di mana ketidakadilan dan kemelaratan dapat mengantarkan orang pada keyakinan yang salah, maka ortopraksis berarti aktivitas yang mendukung keadilan, yakni praksis liberatif. Karenanya, hermeneutika al-

\footnotetext{
15 Ibid.

16 Ibid.

17 Rudolf Bultmann, Essays, Philosophical and Theological (London: SCM Press, 1955), h.251
} 
Qur'an tentang pembebasan muncul dalam perjuangan konkret demi keadilan dan memperoleh keabsahannya dari situ.

d. Pernyataan doktrin formal pada dasarnya merupakan hasil kerja intelektual yang telah lestari berabad-abad. Dalam prosesnya, kerja tersebut dibarengi perselisihan religio-politik yang turut mempengaruhi pembentukannya.

e. Teologi islam secara umum dan studi-studi al-Qur'an secara khusus menjadi semakin kaku dalam proses sistematisasi teologi, dan tidak mampu berurusan dengan semua bentuk yang berbeda, di dalam komunitas sejarah kaum muslim maupun di luarnya.

f. Terdapat konfirmasi di dalam al-Qur'an bahwa ayat-ayat al-Qur'an diturunkan dalam konteks tertentu, demikian pula soal penerimaan atas kebenaran dan keadilan orang lain. Tetapi kaum muslim konservatif senantiasa menyempitkan basis teologis dalam mendefinisikan iman, islam dan meluaskan basis bagi istilah kufr.

g. Kaum muslim dihadapkan pada usaha pencarian respons al-Qur'an terhadap tantangan yang menghadang umat manusia kini. Yakni usaha untuk menemukan penafsiran yang sesuai untuk konteks kini. ${ }^{18}$

\section{Gagasan Hermeneutika Farid Esack}

Hermeneutika sebagai sebuah disiplin ilmu tafsir, tidak hanya menggarap urusan bagaimana proses memahami dan menafsirkan "yang benar itu" (aspek epistemologis dan metodologis), melainkan juga menggarap asumsi-asumsi dasar dan kondisi serta kedudukan manusia serta segala faktor yang terlibat dalam proses penafsiran yang dimaksud (aspek ontologis dan aksiologis). Asumsi yang dibangunnya adalah 'asumsi pluralitas', yaitu bahwa pemahaman dan penafsiran itu plural secara niscaya. Hal ini karena dalam segala aspeknya, kehidupan manusia itu plural.

Dari penggalian terhadap gagasan hermeneutika kerukunan yang dibangunnya, paling tidak ada empat tujuan pokok gagasan hermeneutika yang ditawarkan Esack, yaitu:

1. Menunjukkan "sangat-mungkin"nya untuk hidup dalam keimanan kepada al-Qur'an sekaligus dalam konteks kekinian bersama orang-orang yang berbeda agama, bekerja bersama mereka untuk membentuk masyarakat yang lebih manusiawi.

2. Mengedepankan gagasan hermeneutika al-Qur'an sebagai suatu sumbangsih bagi pengembangan pluralisme teologi dalam Islam.

\footnotetext{
${ }^{18}$ Farid Esack, Membebaskan Yang tertindas, h. 36-37
} 
3. Mengkaji ulang cara al-Qur'an mendefinisikan "golongan kita" dan "golongan lain" (yang beriman dan yang tidak beriman) untuk dapat memberi ruang bagi kebenaran dan keadilan orang lain dalam teologi pluralisme demi pembebasan.

4. Menggali hubungan antara eksklusivisme keagamaan dan sebentuk konservatisme politik di satu sisi, dan inklusivisme keagamaan dan sebentuk politik progresif di sisi lain, dan untuk memberikan alasanalasan Qur'ani bagi yang terakhir. ${ }^{19}$

Berdasarkan asumsi dasar tersebut, dapatlah dikatakan bahwa konflik dan berbagai pertikaian yang bahkan sering membawa korban sebagai akibat dari perbedaan pandangan tersebut sebenarnya merupakan sesuatu yang naif. Setiap orang ingin agar pemahaman dan penafsirannya-lah yang paling benar (truth claim), sementara yang lain dan berbeda dengannya dianggap salah, dan karenanya harus dipaksa untuk menerima kebenarannya. Jika sikap seperti ini yang ditonjolkan maka dipastikan akan selalu terjadi benturan antar kelompok masyarakat.

Berdasarkan teori hermeneutikanya, Esack menjelaskan dan memberikan landasan teologis bagi terlaksananya kerja sama antar (dan intern) umat beragama, khususnya muslim-non muslim. Dalam hal ini Esack mengawinkan praksis dan tafsir sekaligus dalam rangka menghadirkan hermeneutika yang membebaskan. Kondisi riil negaranya (Afrika) saat itu betul-betul kental dengan nuansa hegemoni Apartheid, penindasan, pengekangan, dominasi mayoritas, termasuk pemaksaan kehendak pada kaum minoritas.

Dengan hermeneutika kerukunan (solidaritas)nya, Esack ingin menawarkan dua hal penting: pertama, memperlihatkan bahwa al-Qur'an tidak mencegah kaum muslim untuk bekerja sama dengan orang lain demi menegakkan keadilan dan kebenaran. Menurutnya, teks-teks al-Qur'an yang seolah melarang hal itu, bila ditinjau dari konteks historisnya, sangat mendukung bagi hermeneutika al-Qur'an tentang pluralisme agama dan kebebasan. Kedua, memperlihatkan bahwa al-Qur'an dan teladan Nabi mendukung kerja sama dan solidaritas antar iman untuk keadilan dan kebenaran. Solidaritas ini tidak dilandasi oleh kehendak yang samar untuk perdamaian dan ketenteraman, melainkan pada perjuangan menentang ketidakadilan demi menciptakan dunia yang aman bagi umat manusia, dan

\footnotetext{
${ }^{19}$ Ibid., h. 38
} 
membebaskan penghuninya dari perbudakan demi menjalankan ibadah kepada Tuhan dengan leluasa.

Berkaitan dengan pandangan al-Qur'an tentang perjuangan untuk menegakkan keadilan, kerjasama, kerukunan, pembebasan dan pluralisme, Esack menyatakan bahwa Tuhan telah menyebut al-nas dan hubungan antara jalan-Nya dengan jalan al-nas itu, terutama yang diberikan-Nya kepada yang tertindas dan tersisih, dan pentingnya menegakkan keadilan. Al-Qur'an mengajar para aktivis yang beriman di tengah-tengah perjuangan mereka mewujudkan tauhid, takwa, dan memberi perubahan konkret bagi kaum tertindas melalui jihad. Dalam hal ini, Esack mengutip pernyataan Ayatullah Mahmud Taleghani, "jalan Tuhan adalah jalan yang mengarah pada kebaikan bagi seluruh manusia, jalan keadilan, jalan kemerdekaan manusia agar tak satu kelompok pun menjadi dominan... mengambil bagi dirinya sendiri seluruh sumber alam yang telah disediakan Tuhan untuk semua" ${ }^{20}$ Mengupayakan hermeneutika al-Qur'an dalam situasi ketidakadilan, kata Esack, berarti menjalani teologi dan mengalami iman sebagai solidaritas dengan kaum tertindas dan tersisih dalam perjuangan pembebasan.

\section{Membaca Ulang al-Qur'an tentang Makna "Kaum Lain"}

Al-Qur'an menampilkan perspektif ketuhanan universal dan inklusivistik yang merespon ketulusan dan komitmen seluruh hamba-Nya. Dua pertanyaan muncul di sini. Pertama, bagaimana penafsiran tradisional bisa menampilkan citra parokial tentang Tuhan yang tak berbeda dengan postulat kaum Yahudi dan Nasrani Madinah yang banyak dicela oleh alQur'an? Yakni citra yang menggambarkan Tuhan sebagai milik sekelompok kecil manusia yang, setelah menetapkan pilihan-Nya, membutakan mata pada komitmen spiritual dan sosial tulus dari siapa pun di luar lingkaran itu. Kedua, bagaimana universalitas pesan al-Qur'an berkaitan dengan eksklusivisme dan pengutukan kaum lain, bahkan anjuran mengangkat senjata menentang kaum lain? ${ }^{21}$

Menurut Esack, para penafsir awal kurang memperlihatkan pemahaman atas konteks historis turunnya wahyu tertentu secara keseluruhan, meski mereka tahu konteks masing-masing ayat bertalian dengan agama lain. Akibatnya, muncul generalisasi penolakan atau pencelaan terhadap agama lain, tanpa memperhatikan konteks sosiohistoris dari teks-teks yang digunakan untuk mendukung sikap itu. Padahal, al-

${ }^{20}$ Ibid., h. 149

${ }^{21}$ Ibid., h. 191 
Qur'an memperlihatkan watak gradual dan kontekstual dalam memandang kaum lain. ${ }^{22}$

Ide tentang perkembangan sikap al-Qur'an yang gradual dan kontekstual ini memiliki beberapa implikasi penting. Pertama, orang tak bisa berbicara tentang "posisi final al-Qur'an" terhadap kaum lain, dan kedua, adalah tidak tepat untuk menerapkan teks-teks celaan secara universal dan ahistoris kepada semua yang didefinisikan sebagai "ahli kitab" atau "kafir". Mengapa? Hal ini karena iman dan prilaku bukanlah unsur genetis, sekalipun di dalam komunitas yang dianggap homogen dan tak berubah. Untuk mencegah generalisasi tak adil seperti inilah maka teks-teks yang mencela komunitas kaum beragama lain biasanya diikuti atau didahului oleh pernyataan pengecualian (misal; Ali Imran [3]: 75), atau kalimat-kalimat bersyarat atau pengkhususan (spt; al-Baqarah [2]: 109; al-Maidah [5]: 66; alHaji [22]: 17 dll). ${ }^{23}$

Bagaimana sikap umum al-Qur'an terhadap penganut agama lain? Esack menjelaskannya berikut. Pertama, al-Qur'an menghubungkan dogma dengan eksploitasi sosioekonomi. Ada keterkaitan antara ortodoksi dengan ortopraksis. Dalam kasus penolakan pesan Nabi tentang tauhid dan keadilan sosial oleh komunitas ataupun individu di Makkah dan Madinah, al-Qur'an misalnya, menerangkan bahwa penyangkalan dan ketidakpedulian pada tauhidlah yang mengakibatkan penindasan sosial dan ekonomi masyarakat Makkah. Hal ini bisa dilihat dari penjelasan al-Qur'an pada surat-surat Makkiyah: al-Muthaffifun [83]: 1-11; al-Takatsur [102] yang menegaskan bahwa penumpukan kekeyaanlah yang memalingkan manusia dari percaya kepada Tuhan dan Hari Pembalasan. Qs. Al-Humazah [104] mengaitkan kekuatan khayali kekayaan dengan upaya mencela dan memfitnah kaum muslim awal di Makkah. Selanjutnya surat al-Balad [90] secara tersirat mengaitkan kufr dengan penolakan untuk bermurah hati dan kasih sayang kepada orang lain. ${ }^{24}$

Teks-teks Madaniyah yang mencela kaum Yahudi dan Nasrani yang dijumpai Nabi dan kaum muslim awal menekankan keterkaitan serupa antara keimanan yang "keliru" dengan eksploitasi sosial-ekonomi terhadap orang lain. Menurut al-Qur'an, Yahudi dan Nasrani menjustifikasi eksploitasi terhadap kaum mereka sendiri dengan dasar bahwa kitab suci mereka membolehkan praktek-praktek itu. Al-Qur'an mencela eksploitasi

\footnotetext{
22 Ibid., h. 192

${ }^{23}$ Ibid., h. 192-193

${ }^{24}$ Ibid., h. 202
} 
atas ketidaktahuan orang-orang buta huruf (al-Baqarah: 78) oleh para pendeta Ahli Kitab. Pandangan merendahkan dan eksploitasi terhadap kaum pinggiran oleh sebagian ahli kitab terlihat dari alasan mereka bahwa mereka tak punya kewajiban moral untuk bersikap adil kepada orang-orang yang buta huruf (Ali Imran: 75). Meskipun terikat sumpah dengan Tuhan yang Transenden, mereka melanggarnya dengan melakukan eksploitasi terhadap makhluk Tuhan.

Kedua, al-Qur'an secara eksplisit dan tegas mencela eksklusivisme agama yang sempit sebagaimana ditunjukkan oleh kaum Yahudi dan Nasrani yang dijumpai Nabi di Hijaz. Al-Qur'an bersikap keras dalam mencela arogansi tokoh keagamaan Yahudi serta eksklusivisme tribalisme yang membuat mereka memperlakukan orang-orang di luar kaum mereka sendiri, terutama yang lemah, dengan sikap menghina. Penghinaan pihak lain ini, jelas al-Qur'an, berakar dari kesombongan karena merasa sebagai umat pilihan Tuhan. Banyak di antara mereka percaya bahwa mereka tidak sama dengan orang lain, dan mereka adalah "kekasih Allah satu-satunya, bukan yang lain" (al-Jumu'ah [62]: 6). Al-Qur'an menuturkan, mereka mengklaim posisi istimewa itu hanya dengan menyebut diri mereka sebagai Yahudi dan Nasrani. Itu adalah klaim yang didasarkan pada sejarah, kelahiran, dan kesukuan, bukan pada praksis dan moralitas. ${ }^{25}$

Al-Qur'an juga mencela klaim sebagian Ahli Kitab bahwa kehidupan akhirat hanyalah untuk mereka dan "tidak diperuntukkan bagi orang lain" (al-Baqarah: 94,111). Al-Qur'an juga mengambil sikap tajam terhadap bualan kaum Yahudi dan Nasrani bahwa keimanan mereka adalah satusatunya keimanan yang diterima (al-Baqarah: 111-113).

Ketiga, al-Qur'an bersikap eksplisit dalam penerimaannya atas pluralisme agama. Dalam hal ini, al-Qur'an menawarkan visi tentang Tuhan yang merespon seluruh manusia dan menerima ketulusan dan kebaikan semua orang beriman. Jadi al-Qur'an menjadikan kepercayaan pada keaslian semua agama wahyu sebagai syarat keimanan (al-Baqarah: 136,285; Ali Imran: 84).

Al-Qur'an mengakui keabsahan semua agama wahyu dalam dua hal: 1) ia menerima keberadaan kehidupan religius komunitas lain yang semasa dengan kaum muslim awal, menghormati hukum-hukum, norma-norma sosial, dan praktek-praktek keagamaan mereka; dan 2) ia menerima pandangan bahwa pemeluk-pemeluk setia agama-agama ini juga akan

\footnotetext{
${ }^{25}$ Ibid., h. 203-204
} 
mendapatkan keselamatan (al-Baqarah: 62). Dua sikap al-Qur'an terhadap kaum lain inilah yang bisa dijadikan sebagai dasar pluralisme agama. Pengakuan al-Qur'an atas pluralisme agama tampak jelas tidak hanya dari sisi penerimaan kaum lain sebagai komunitas sosioreligius yang sah, tetapi juga dari penerimaan kehidupan spiritualitas mereka dan keselamatan melalui jalan yang berbeda itu. ${ }^{26}$

Dalam konteks ini, Esack menyimpulkan bahwa keunggulan amal saleh bukan berarti posisi superior sosioreligius yang permanen bagi komunitas muslim. Kaum muslim sebagai sebuah entitas sosial tidaklah superior dibanding yang lain, sebab posisi semacam itu akan menempatkan mereka dan Tuhan parokial mereka ke dalam kategori yang sama dengan mereka yang dicela al-Qur'an karena kesombongan dan hawa nafsu untuk mengkhususkan Tuhan bagi suatu komunitas yang sempit. Teguran alQur'an pada kaum yang lain adalah agar mereka tidak mendasarkan klaim superioritas mereka pada prestasi nenek moyang mereka (al-Baqarah: 134). Tak ada alasan bahwa ini pun berlaku bagi kaum muslim pasca nabi Muhammad.

Dalam pandangan al-Qur'an, inklusivisme lebih superior dibandingkan eksklusivisme. Inklusivitas tak hanya berupa keinginan untuk menerima keberadaan setiap ide dan praktek, tetapi juga mendorong ke arah tujuan tertentu, seperti membebaskan manusia dari ketidakadilan dan perbudakan kepada manusia lainnya sehingga mereka dapat dengan bebas menyembah Tuhan. Menurut penjelasan al-Qur'an, adanya kepercayaan (di kalangan orang-orang kafir) bahwa seseorang tak akan dimintai pertanggungjawaban di depan Allah dan praktek syirk, secara intrinsik terkait dengan praktek yang ada di Arab ketika itu (periode Makkah). Untuk memastikan terjaminnya keadilan bagi semua, adalah penting bagi nabi Muhammad dan kaumnya untuk bekerja secara aktif melawan berbagai kepercayaan itu dan untuk tidak memberi mereka posisi yang setara. ${ }^{27}$

\section{Menakar Kekuatan Hermeneutika Farid Esack}

Sulit dipungkiri, peran Esack dengan perangkat organisasi pendukungnya dalam mensosialisasikan pemikiran keagamaan yang tipikal Afsel. Terlebih, pemikiran keagamaan yang digagasnya langsung merujuk pada sumber pokok ajaran Islam, yakni al-Quran. Apa yang dirumuskan Esack sebagai hermeneutika pembebasan al-Quran merupakan catatan kaki

${ }^{26}$ Ibid., h. 207

${ }^{27}$ Ibid., h. 224 
dari produk refleksi pemikiran teologis dan pergumulan praksis dengan hegemoni, dominasi dan represi rezim apartheid yang menggencet rakyat Afsel pada umumnya.

Metode hermeneutika Esack tidak lahir dengan sendirinya tetapi didasarkan atas berbagai pemikiran, khususnya Gueterrez, Arkoun dan Rahman. ${ }^{28}$ Esack mengambil konsep teologi pembebasan dari Gueterrez dan double movement Rahman untuk menjelaskan soal praksis dan semangat teks, dan mengambil konsep regresif-progresif Arkoun untuk memberikan landasan kontekstualisasi teks pada masa kekinian. Selain itu, Esack juga berbeda dalam penempatan posisi penafsiran. Dalam pola hermeneutika biasa, eksistensi teks dalam konteks (lokus penafsiran) ditentukan oleh "kuasi transformatif" yang mampu menggeser paradigma atau model cara baca terhadap teks. Akan tetapi, Esack justru menempatkan posisi sentral penafsiran pada teks partikular (prior texts) dan responsinya terhadap konteks tanggapan audiens, serta menentukan arti penting relevansi teks dalam konteks kontemporer. Sedemikian, sehingga ditemukan "makna baru" yang dibutuhkan. Yakni, makna baru yang sesuai dengan kebutuhan dan konteks partikular (sosial-politik-keagamaan) Afrika Selatan. ${ }^{29}$

Teori hermenutika Esack ini didasarkan atas pembacaannya terhadap realitas praksis. Ketika realitas tersebut harus dirubah, karena terjadi ketimpangan, maka di sana dicarikan justifikasinya dari ayat-ayat, karena menurutnya, semangat teks sesunguhnya adalah pembebasan dari ketimpangan. Inilah rumusan khas hermeneutika Esack yang tidak ditemukan dalam hermeneutika lainnya. Konsep kerja sama Esack benarbenar di dasarkan atas pembacaannya atas realitas praksis Afrika Selatan dan metode hermenutika yang dikembangkannya. Karena itu, hasilnya memang sering berbeda atau bahkan berseberangan dengan penafsiran-penafsiran klasik. Akan tetapi, Esack tidak berarti sama sekali meninggalkan tafsir klasik. Ia tetap dan justru menggunakannya dalam upaya mendukung pemikiran dan proses hermeneutikanya.

Esack meyakini bahwa al-Qur'an diwahyukan secara progresif sesuai dengan kebutuhan masyarakat pada masa pewahyuan, dan pada masa selanjutnya harus terus dibaca seperti itu. Pada tahap awal, Esack berupaya menetapkan identitas al-Qur'an sebagai sebuah wahyu yang diturunkan secara bertahap. Ini adalah satu-satunya cara untuk memahami sebagian

${ }^{28}$ Ibid., h. 120

${ }^{29}$ Ibid., h. 121 
besar garis pedomannya (buda) yang abstrak kepada kemanusiaan melintasi ruang dan masa. Prinsip tadrij atau pewahyuan secara gradual sangat penting di sini. Hal ini telah jelas dinyatakan dalam al-Qur'an sendiri pada surat alIsra': 106 dan al-Furqan: 32. Terdapat teknik yurisprudensial lain yang digunakan oleh para ilmuwan tradisional yang menguatkan posisi ini. Teknik-teknik ini adalah asbab al-nu₹ul dan naskb. ${ }^{30}$

Menurut Esack, meyakini signifikansi al-Qur'an yang abadi tidak sama dengan meyakini sebuah teks yang tak memiliki waktu dan ruang (abistoris). Esack selalu menegaskan bahwa hermeneutika secara umum harus dipahami sebagai ilmu yang merefleksikan bagaimana sebuah kata atau peristiwa masa lalu dan budayanya bisa dipahami dan bermakna secara eksistensial pada situasi kekinian. Hermeneutika sebagai metode memahami al-Qur'an sangat mendesak penerapannya. Hal itu, menurutnya, karena umat Islam, meskipun sangat bersepakat tentang sifat divinitas al-Qur'an, memiliki perbedaan yang cukup lebar tentang peran al-Qur'an dan cara memahaminya. Dalam kerja penafsiran, hermeneutika akan mengangkat persoalan tentang pergeseran yang terjadi dalam horizon-horison audiens yang berbeda dan transformasi antara horizon masa lalu dan masa kini tentang ekspektasi terhadap teks.

Bagi Esack, keilmuan Islam tradisional setidaknya akan memiliki tiga kendala untuk bersinergi dengan hermenutika sebagai sebuah metode memahami al-Qur'an, yaitu: Pertama, keilmuan Islam tradisional meskipun memiliki cara pemahaman tersendiri tentang kontekstualisasi dalam memahami al-Qur'an, benar-benar memegang teguh ide bahwa al-Qur'an adalah kalam Tuhan yang trans-kontekstual dan oleh karenanya qadim. Di sisi lain, desakan hermeneutika atas konteks dan kontingensi manusia dalam upaya pencarian makna menunjukkan bahwa al-Qur'an tidak berarti apapun di luar konteks sosio-historisnya, namun selamanya ia adalah sebuah teks yang memerlukan interpretasi.

Kedua, penekanan hermeneutika pada agensi manusia dalam memproduksi makna bertentangan dengan ide keilmuan tradisional yang menegaskan bahwa Tuhan bisa membekali manusia dengan sebuah pemahaman yang paling tepat dan sempurna. Esack mengatakan: "memberi peran besar kepada manusia berarti memandang bahwa makna itu sendiri merupakan sebuah pertarungan dalam relasi-relasi kuasa; ketuhanan-pun

\footnotetext{
${ }^{30}$ Farid Esack, Menghidupkan Al-Qur'an; Dalam Wacana dan Prilaku, (Depok: Insani Press, 2006), h. 167
} 
berada di dalamnya dan tak bisa dianggap transenden di luar pertarungan itu sebagai penjamin makna paling akhir." ${ }^{31}$

Ketiga, pada satu sisi, keilmuan Islam tradisional membuat pembedaan yang ketat antara pewahyuan, penafsiran, dan penerimaan. Sementara itu, hermeneutika penerimaan, di sisi lain, tidak berusaha menemukan kehendak orisinal sang author yang tentu saja sulit diprediksi (apalagi dalam kasus Tuhan). Sebaliknya, ia mempelajari konstribusi pemahaman yang terus dan selalu berubah tentang teks.

Bagi Esack, persoalan fundamental dalam penafsiran al-Qur'an adalah tentang; oleh siapa dan pada kepentingan siapa kerja hermeneutika diperuntukkan. Memahami teks menurutnya mencakup suatu kesadaran akan tiga unsur yang saling terkait, yakni teks dan author, penafsir, dan penafsiran. ${ }^{32}$

Meskipun seseorang sadar akan pentingnya hermeneutika dan dengannya ia memahami al-Qur'an, ia masih tidak mampu secara memadai menjawab ketakutan yang dicemaskan keilmuan tradisional. Dalam hal ini, Esack memberikan seperangkat panduan yang ia sebut sebagai kunci-kunci bermeneutika untuk menafsirkan al-Qur'an. Kunci-kunci ini tidak hanya sebagai berfungsi sebagai sebuah lensa optic yang dengannya orang harus mengamati al-Qur'an, namun juga berarti sebagai pematah setiap penafsiran yang bertendensi sembarangan.

Kunci-kunci ini ketika digunakan secara seksama diharapkan akan membekali orang beriman dengan seperangkat instrument guna memahami pesan transenden al-Qur'an, walaupun, menurut Esack, tetap berujung pada perdebatan. Bagi Esack, kunci-kunci ini hendak merefleksikan bahwa praktek seseorang (praksis) akan menjadi ujian atas ketepatan penafsiran seseorang. Tidak ada mukjizat dan keajaiban yang akan datang dengan menerapkan ini. Ini hanya sebuah proses trial and error, namun semacam kompas untuk membimbing seseorang mengarungi samudera kehidupan yang bergolak.

Kunci-kunci hermeneutika yang diajukan oleh Esack dikembangkan dari aktivitasnya sebagai seorang intelektual organik saat berjuang melawan rezim Aphartheid di Afrika Selatan. Kunci-kunci itu adalah taqwa (integritas dan kesadaran yang terkait dengan kehadiran Tuhan), taubid (keesaan Tuhan), nas (manusia atau rakyat), mustadl'afin fi al-ardl (kaum tertindas di muka bumi), 'adl dan qisth (keadilan), dan jïhad (perjuangan dan praksis).

31 Ibid., h. 190

${ }^{32}$ Farid Esack, Samudra Al-Qur'an, (Jakarta: Mizan 2007), h. 89 
Kunci-kunci tersebut dimaksudkan untuk memperlihatkan bagaimana hermeneutika pembebasan al-Qur'an bekerja, dengan pergeseran yang senantiasa berlangsung antara teks dan konteks berikut dampaknya terhadap satu sama lainnya. ${ }^{33}$ Esack juga menggarisbawahi arti pentingnya kunci-kunci tersebut sebagai perangkat untuk memahami al-Qur'an, terutama bagi suatu masyarakat tidak hanya kasus Afrika Selatan yang diwarnai penindasan dan perjuangan antariman demi keadilan dan kebebasan. ${ }^{34}$

Kunci-kunci di atas juga digunakan untuk tujuan tertentu dan terstruktur; dua kunci pertama taqwa dan taubid dimaksudkan sebagai pembangunan kriteria moral dan doktrinal yang akan menjadi "lensa teologis" dalam membaca al-Qur'an secara umum dan terutama teks-teks tentang pluralisme dan solidaritas antar iman. ${ }^{35}$ Dua kunci berikutnya al-nas (manusia) dan al-mustadl'afuna fi al-ardl (kaum tertindas) sebagai pengukuhan terhadap konteks atau lokasi aktifitas penafsiran. Sedang dua kunci terakhir 'adl-qisth (keadilan) dan jihad (perjuangan) merupakan refleksi dari metode dan etos yang menghasilkan dan membentuk pemahaman kontekstual tentang firman Tuhan dalam masyarakat yang diwarnai ketidakadilan. ${ }^{36}$

Pencarian Esack akan hermeneutika al-Qur'an tentang pluralisme dan kerukunan--demi pembebasan Afrika Selatan berakar pada gabungan antara keragaman bangsa Afsel dan komitmen pribadinya pada keadilan yang komprehensif. Ia lebih fokus pada pemikiran ulang tentang pendekatan terhadap al-Qur'an dan kategori "teologis" tentang kawan dan lawan dalam perjuangan demi kebebasan dari eksploitasi ekonomi dan diskriminasi rasial, walaupun penerapannya diarahkan lebih luas dari itu.

Bagi Esack, kewajiban memahami al-Qur'an dalam konteks penindasan bagi seorang muslim memiliki aspek ganda. Pertama, harus memperlihatkan bagaimana tafsiran dan keyakinan tradisional atas suatu ayat berfungsi sebagai ideologi yang melegitimasi ketidakadilan. Kedua, mengakui kesatuan umat manusia, mencari dimensi keagamaan atas situasi ketidakadilan dari ayat dan menggunakannya sebagai motor pembebasan. ${ }^{37}$

Teologi pembebasn yang diyakini Esack adalah salah satu upaya untuk melepaskan agama dari struktur sosial, politik dan keagamaan yang

\footnotetext{
${ }^{33}$ Abdul Mustaqim, Sahiron Syamsudin, Studi Al-Qur'an Komtemporer; Wacan Baru Berbagai Metodologi Tafsir, (Yogyakarta: Tiara Wacana, 2002), h. 200

${ }^{34}$ Farid Esack, Membebaskan Yang... op. cit., h. 123

35 Ibid.

${ }^{36}$ Ibid., h. 124; Abdul Mustaqim, op. cit., h. 203

${ }^{37}$ Farid Esack, Membebaskan Yang... op. cit., h. 35
} 
menuntut kepatuhan mutlak, menuju ke arah kebebasan semua manusia dari segala bentuk ketidakadilan dan ketertindasan termasuk dalam hal etnis, gender, kelas dan agama. Teologi pembebasan berusaha untuk meraih hal ini lewat kolaborasi dan kerja sama dengan mereka yang mencari pembebasan sosial dan ekonomi. Sebuah teologi pembebasan Islam merujuk inspirasinya dari al-Qur'an dan perjuangan semua Nabi. Hal itu dilakukan dengan jalan memahami al-Qur'an dan keteladanan para Nabi dalam suatu proses refleksi teologis bersama dan berkesinambungan demi sepenuhnya peningkatan praksis pembebasan.

\section{Kesimpulan}

Terjadinya konflik dalam kehidupan beragama bisa disebabkan faktor internal dan eksternal. Dalam konteks inilah kita bisa belajar dari konsep hermeneutika Farid Esack tentang pluralisme dan inklusivisme, mengingat adanya kemiripan konteks antara Afrika Selatan dari mana Esack berasal dan Indonesia yang sama-sama multikultural dan multi agama. Menurut Farid Esack al-Qur'an secara eksplisit dan tegas mencela eksklusivisme agama yang sempit sebagaimana kaum Yahudi dan Nasrani Madinah. AlQur'an juga bersikap keras dalam mencela arogansi tokoh keagamaan Yahudi serta eksklusivisme tribalisme yang membuat mereka memperlakukan orang-orang di luar kaum mereka sendiri, terutama yang lemah, dengan sikap menghina.

Memang dalam masyarakat yang multi agama seperti Indonesia ini akan sangat rawan jika masing-masing pemeluk agama mengedepankan pemikiran dan sikap eksklusivistik, apalagi eksklusifisme yang didasarkan pada kesukuan dan keturunan. Padahal Tuhan sendiri menghargai seseorang bukan karena ia berasal atau bagian dari komunitas tertentu, melainkan karena prestasi dan karya-karyanya. Sikap semacam ini berawal dari anggapan bahwa agama kitalah yang paling benar, paling baik dan paling murni. Akibatnya, kita cenderung melihat agama lain atau kepercayaan lain sebagai tidak benar, tidak baik dan tidak murni. Dalam kehidupan sosial, sikap ini mengakibatkan munculnya sikap lain, yaitu tertutup, menyendiri dan enggan menerima pendapat atau masukan dari luar. Komarudin Hidayat mengingatkan, eksklusivisme agama akan sangat berbahaya dalam kehidupan berbangsa dan bernegara. Apalagi, ketika negara sebagai sebuah state gagal, masyarakat akan mencari etno baru dan salah satunya adalah agama. $^{38}$

38 http:/ / bestsonmanurung.blogspot.com/2006/05/ hindari-ksklusivisme-agama.html 


\section{DAFTAR PUSTAKA}

Arkoun, Mohamed., Al-Islam al-Akblâq wa al-Siyâsah, Beirut: Markaz alInma`al-Qaumi, 1990

Bultmann, Rudolf, Essays, Philosophical and Theological, London: SCM Press, 1955

Esack Farid, Menghidupkan Al-Qur'an; Dalam Wacana dan Prilaku, Depok: Insani Press, 2006

, Membebaskan Yang Tertindas, Al-Qur'an Liberalisme Pluralisme, terj. Watung Budiman, Bandung: Mizan, 2000

, On Being A Muslim, Menjadi Muslim di Dunia Modern, terj. Dadi

Darmadi dan Jajang Jahroni, Jakarta: Erlangga, 2004

-----, Samudra Al-Qur'an, Jakarta: Mizan 2007

Martin, Richard C. (ed), Approach to Islam in Religious Studies, Tuscon: The University of Arizona, 1985

Mustaqim, Abdul, dan Sahiron Syamsudin, Studi Al-Qur'an Komtemporer; Wacan Baru Berbagai Metodologi Tafsir, Yogyakarta: Tiara Wacana, 2002

Soleh, Ahmad Khudlori dalam "Kekerasan Religius" dalam wnw.scribd.com

Sumartana, TH. et. al, Pluralisme, Konflik dan Pendidikan Agama di Indonesia, Yogyakarta: Dian/ Interfidei, 2001

Whitehead, Alfred North, Religion in the Making, New York: New American Library, 1974

bttp:/ / bestsonmanurung.blogspot.com/2006/05/ hindari-kesklusivisme-agama.btml

http://regional.kompas.com/ read/2011/02/08

http:/ / wom.farid esack.com

Kompas.com, diakses pada 6 Pebruari 2011 